\title{
PENGARUH PELATIHAN KOMBINASI FOOTWORK TERHADAP PENINGKATAN KELINCAHAN DAN VOLUME OKSIGEN MAKSIMAL $\left(\mathrm{VO}_{2}\right.$ Maks)
}

\author{
Muhammad fardiansyah ${ }^{1}$, I Ketut Iwan Swadesi², Ni Luh Kadek Alit Arsani ${ }^{3}$ \\ Jurusan IImu Keolahragaan, Fakultas Olahraga dan Kesehatan \\ Universitas Pendidikan Ganesha \\ Singajara, Indonesia
}

e-mail: \{muhammadfardiansyah99@gmail.com¹, swadesi2000@yahoo.co.id², alit_arsani@yahoo.com³\}

\begin{abstract}
Abstrak
Penelitian ini bertujuan untuk mengetahui pengaruh pelatihan kombinasi footwork terhadap peningkatan kelincahan dan $\mathrm{VO}_{2}$ Maks. Jenis penelitian adalah Penelitian eksperimen, dengan desain "The Non Randomized Pretest Posttest Design Control Group" Subjek penelitian adalah siswa putra SMP Muhammadiyah 2 Singaraja tahun pelajaran 2017/2018 berjumlah 30 orang siswa. $\mathrm{VO}_{2}$ Maks diukur dengan tes MFT dan kelincahan diukur dengan ilionis agility run. Data dianalisis dengan uji $\mathrm{t}$ independent pada taraf signifikansi $\alpha<0,05$. Dari hasil analisis data didapatkan untuk variabel kelincahan pada kelompok kontrol rata-rata gain score adalah: 1,8534 dan pada kelompok perlakuan sebesar 3.0534. Sedangkan pada variabel $\mathrm{VO}_{2}$ Maks, pada kelompok kontrol didapatkan rata-rata gain score sebesar 2,5666 dan pada kelompok perlakuan sebesar 3,96. Hasil uji normalitas dan homogenitas didapatkan data berdistribusi normal dan homogen. Hasil uji independent t-test didapatkan rata-rata $\mathrm{VO}_{2}$ Maks pada kelompok perlakuan lebih tinggi secara signifikan dibandingkan dengan kelompok kontol dengan nilai signifikansi $\alpha=0,033(<0,05)$. Sedangkan untuk variabel kelincahan didapat rata-rata pada kelompok perlakuan lebih tinggi secara signifikan dibandingkan dengan kelompok kontol dengan nilai signifikansi $\alpha=0,023(<0,05)$. Disimpulkan bahwa; (1) pelatihan kombinasi footwork berpengaruh signifikan terhadap peningkatan $\mathrm{VO}_{2}$ Maks siswa ekstrakurikuler SMP Muhammadiyah 2 Singaraja tahun pelajaran 2017/2018. (2) pelatihan kombinasi footwork berpengaruh signifikan terhadap peningkatan kelincahan siswa ekstrakurikuler SMP Muhammadiyah 2 Singaraja tahun pelajaran 2017/2018.
\end{abstract}

Kata Kunci: kelincahan, pelatihan kombinasi footwork, $\mathrm{VO}_{2}$ Maks.

\begin{abstract}
This study was aimed to investigate the effect of footwork combination training on improving agility and $\mathrm{VO}_{2} \mathrm{Max}$. This research was an experimental research, with the design "The Non Randomized Pretest Posttest Design Control Group". The subjects were the students of SMP Muhammadiyah 2 Singaraja of academic year $2017 / 2018$ as many as 30 students. $\mathrm{VO}_{2}$ Max was measured by MFT test and agility was measured by the illionis agility run. Data were analyzed by independent $t$ test at significance level $\alpha<0,05$. From the data analysis obtained for agility variables in the control group the mean of gain score was 1.8534 and in the treatment group was 3,0534. The mean of $\mathrm{VO}_{2} \mathrm{Max}$ volume in the control group was 2.5666 and in the treatment group was 3.96. Normality and homogeneity test results were normal and homogeneous distribution data. The result of the independent t-test showed that the average of $\mathrm{VO}_{2}$ Maks in the treatment group was significantly higher than in the control group with significance value $\alpha=0,033(<0,05)$. While for the agility variable showed that in the treatment group was significantly higher compared with the control group with significance value $\alpha=0,023$ $(<0,05)$. It was concluded that; (1) footwork combination training increased $\mathrm{VO}_{2}$ maximal volume of extracurricular student SMP Muhammadiyah 2 Singaraja of academic year 2017/2018; (2) Footwork combination training increased the agility of extracurricular student SMP Muhammadiyah 2 Singaraja of academic year $2017 / 2018$.
\end{abstract}

Keywords: agility, footwork combination training, $\mathrm{VO}_{2} \mathrm{Max}$ 


\section{PENDAHULUAN}

Olahraga bulutangkis di Indonesia sudah dikenal sejak lama, sehingga olahraga ini merupakan salah satu cabang olahraga yang populer di kalangan masyarakat Indonesia. Menurut James Poole (2011:4), bulutangkis merupakan olahraga yang masih terus berkembang, makin populer, membutuhkan ketangkasan, tantangan, dan memberikan banyak kesenangan. Oleh sebab itu dapat disimpulkan bahwa, bulutangkis merupakan permainan yang sangat digemari oleh masyarakat di seluruh dunia tanpa memandang umur, jenis kelamin maupun status sosial. Mengenai tujuan dan cara bermainnya menyerupai tenis lapangan, keduanya menggunakan lapangan yang berbentuk empat persegi panjang dan raket untuk memukul suatu benda yang dimainkan dengan menggunakan net, raket, dan shuttlecock dengan teknik pukulan yang bervariasi mulai dari yang relatif lambat hingga sangat cepat disertai gerakan tipuan. Pelatihan olahraga di Indonesia mengacu pada olahraga untuk pencapaian dan peningkatan prestasi, dimana pembinaan prestasi olahraga pada siswa sangat baik diterapkan karena siswa yang pada umumnya masih berusia muda lebih mudah mengkondisikan pelatihan-pelatihan yang akan diberikan untuk mencapai prestasi.

Perkembangan bulutangkis di SMP Muhammadiyah 2 Singaraja kian menurun bisa dilihat dari jumlah siswa sebanyak 30 orang siswa yang terdiri dari kelas VII, VIII, dan IX. Dari siswa yang mengikuti ekstrakurikuler bulutangkis terdapat banyak siswa yang belum menguasai teknik dasar dari olahraga ini. Setelah di amati ada beberapa komponen kondisi fisik yang cenderung mengalami penurunan pada cabang olahraga bulutangkis di SMP Muhammadiyah 2 Singaraja diantaranya kelincahan dan $\mathrm{VO}_{2}$ Maks. Bisa dilihat dari langkah kakinya yang kurang cepat dalam pengambilan shuttlecook. Untuk meningkatkan kemampuan, program pelatihan harus dapat dilakukan secara sistematis, repetitif, durasi, progresif, dan individual, mengikuti prinsip-prinsip serta metode pelatihan yang akurat agar tercapai tujuan yang diharapkan. Oleh karena itu, berdasarkan pengamatan selanjutnya olahraga prestasi pada cabang olahraga bulutangkis perlu ada perhatian khusus karena olahraga ini termasuk olahraga yang sudah lama ada tapi tidak sekalipun prestasi pernah ditorehkan oleh SMP Muhammadiyah 2 Singaraja. Seperti yang diketahui untuk mencapai prestasi yang optimal akan dapat dicapai dengan dimilikinya kondisi fisik yang prima. Sedangkan kondisi fisik yang prima tersebut dapat dimiliki dengan dilakukanya pelatihan yang maksimal. Dalam olahraga bulutangkis unsur-unsur biomotorik yang berperan yaitu kekuatan, $\mathrm{VO}_{2}$ Maks, kelentukan, kelincahan, ketepatan, reaksi, keseimbangan, dan koordinasi.

Footwork atau gerakan langkah kaki merupakan dasar untuk bisa menghasilkan pukulan berkualitas, yaitu apabila dilakukan dalam posisi baik, seorang atlet harus memiliki $\mathrm{VO}_{2}$ Maks gerak kaki tidak bisa dicapai kalau footwork-nya tidak teratur (Aksan, 2013:61). Sedangkan kombinasi adalah menggabungkan beberapa teknik dasar gerakan langkah kaki yang lebih dari satu diantaranya footwork diagonal dan footwork horizontal. Jadi kombinasi footwork adalah menggabungkan beberapa pelatihan dasar gerakan langkah kaki seperti footwork diagonal dan footwork horizontal dengan variasi tiga shuttlecook dipindahkan dari sudut lapangan yang sudah disediakan kemudian dipindahkan dibawah garis net agar bisa menghasilkan gerakan kaki yang berkualitas.

Footwork atau gerakan langkah kaki yang baik sangat berperan penting dalam kesuksesan permainan bulutangkis. Dengan footwork yang benar dan terlatih, pemain dapat menjangkau seluruh titik lapangan dengan lebih mudah dan leluasa. Ringkasnya, footwork adalah pondasi penting dalam kualitas permainan seseorang dalam setiap pukulan yang diluncurkan juga dalam efektifitas strategi permainan secara keseluruhan. Footwork yang baik akan mendukung siswa untuk melakukan penerimaan shuttlecook dengan lebih cepat sehingga memiliki waktu untuk mengatur pengembalian seperti apa yang ingin dia luncurkan. Selain itu, berada di daerah penerimaan shuttlecook yang tepat juga memberi waktu bagi tubuh pemain untuk 
menerima shuttlecook dalam keadaan sempurna sehingga dapat melakukan jenis pukulan yang paling kompleks sekalipun. Hal ini kurang dapat dilakukan jika pemain terlambat menjemput shuttlecook misalnya, akan sulit melakukan smash atau drop shot yang akurat jika drive atau clear sudah terlanjur melewati badan pemain. Intinya, footwork yang baik akan mempermudah pergerakan pemain di lapangan, sehingga stamina dan tenaga yang diperlukan lebih hemat, dan pukulan yang dilancarkan juga lebih terkendali.

Kelincahan atau agility adalah kemampuan untuk mengubah posisi tubuh atau arah gerakan tubuh dengan cepat ketika sedang bergerak cepat, tanpa kehilangan keseimbangan atau kesadaran orientasi terhadap posisi tubuh (kalau dari posisi diam, lalu bergerak cepat, menyangkut komponen $\mathrm{VO}_{2}$ Maks (Nala 2015:152). dalam komponen kelincahan ini membutuhkan komponen kordinasi dan keseimbangan yang prima, seorang atlet agar memiliki kelincahan, yakni kemampuan untuk bergerak secepatnya dari satu titik ke titik lainnya, kemudian secara tibatiba mengubah arah, menghindari atau mengelilingi objek secepatnya memerlukan komponen biomotorik kelincahan. Untuk para atlet kelincahan memiliki peran yang penting demi tercapainya kemampuan penampilan secara baik, seorang atlet sangat perlu untuk memiliki, memelihara, dan menjaganya agar kemampuan agility tetap menjadi satu kesatuan dengan kemampuan fisik lainnya (Widiastuti, 2015:137).

$\mathrm{VO}_{2}$ Maks adalah kesanggupan jantung, paru, dan pembuluh darah untuk berfungsi secara optimal pada keadaan istrahat dan latihan untuk mengambil oksigen dan mendistribusikan ke jaringan yang aktif untuk metabolisme tubuh. (Ismaryati, 2009:77), konsumsi oksigen maksimal disingkat $\mathrm{VO}_{2}$ Maks, artinya $\mathrm{VO}_{2}$ menunjukan volume oksigen yang dikonsumsi, biasanya dinyatakan dalam liter atau mililiter, dan tanda titik diatas $\mathrm{V}$ merupakan tanda yang menyatakan bahwa volume oksigen tersebut dinyatakan dalam satuan waktu, biasanya permenit. Untuk mengetahui besarnya konsumsi oksigen maksimal, harus diketahui terlebih dahulu berapa banyak oksigen yang dihisap dan dihembuskan. Perbedaan diantara keduanya itulah yang merupakan jumlah oksigen yang dikonsumsi dan digunakan oleh sistem trasnpot elektron pada mitochondria untuk menghasilkan energi yang diperlukan oleh jaringan-jaringan yang aktif.p-ISSN :

2613-9693 (cetak) dan e-ISSN : 2613-9685 (online) Maka dari itu peneliti mencoba menerapkan metode pelatihan kombinasi footwork pada siswa peserta ekstrakurikuler bulutangkis di SMP Muhammadiyah 2 Singaraja yang nantinya dapat memberikan kontribusi yang baik dalam meningkatkan kelincahan dan $\mathrm{VO}_{2}$ Maks dalam olahraga bulutangkis serta meningkatkan prestasi siswa SMP Muhammadiyah 2 Singaraja khususnya dalam cabang olahraga bulutangkis. Berdasarkan permasalahan yang telah diuraikan, peneliti tertarik untuk melakukan penelitian tentang "Pengaruh pelatihan kombinasi footwork terhadap peningkatan kelincahan dan volume oksigen maksimal $\left(\mathrm{VO}_{2}\right.$ Maks)".

Berdasarkan latar belakang masalah diatas, maka permasalahan yang dapat dirumuskan adalah sebagai berikut :(1) Apakah pelatihan kombinasi footwork berpengaruh terhadap peningkatan kelincahan pada siswa peserta ekstrakurikuler bulutangkis SMP Muhammadiyah 2 Singaraja ? (2) Apakah pelatihan kombinasi footwork berpengaruh terhadap peningkatan $\mathrm{VO}_{2}$ Maks pada siswa peserta ekstrakurikuler bulutangkis SMP Muhammadiyah 2 Singaraja?

\section{METODE PENELITIAN}

Penelitian ini adalah rancangan eksperimen sungguhan. Dengan tujuan untuk memperoleh informasi dari eksperimen yang sebenarnya dalam keadaan tidak memungkinkan untuk mengontrol atau memanipulasikan semua variabel yang relevan. Penelitian eksperimen pada dasarnya ingin menguji hubungan antara suatu sebab dengan akibat (Kanca, 2010:76).

Alasan mengapa dalam penelitian mengendalikan hanya beberapa aspek saja karena penelitian ini merupakan penelitian 
eksperimen sungguhan dilakukan dengan waktu pelatihan yang singkat sehingga tidak memungkinkan untuk mengendalikan semua variabel yang relevan dari pelatihan yang diberikan.

Melihat dari permasalahan dan tujuan penelitian, maka dalam penelitian ini rancangan yang akan digunakan adalah rancanangan "The Non randomized Pretest Posttest Design Control Group " (Kanca, 2010:94).

Instrumen yang digunakan dalam penelitian ini adalah tes kelincahan yang diukur dengan menggunakan metode lari bolak balik (illinois agility run ) dengan validitas 0,82 dan reliabilitas 0,93 (Nurhasan, 2000:34) sedangkan untuk $\mathrm{VO}_{2}$ Maks menggunakan multistage fitness stage (MFT) 20 meter. Pengumpulan data merupakan tahapan yang paling menentukan dalam suatu penelitian guna mendapat hasil yang diinginkan. Data penelitian ini diperoleh dari pengukuran variabel terikat yaitu kalincahan dan $\mathrm{VO}_{2}$ Maks. Data-data tersebut berupa data tes awal (pretest), dan tes akhir (post-test) pada masingmasing kelompok yaitu kelompok kontrol dan kelompok perlakuan. Tes akhir dilaksanakan setelah kelompok perlakuan diberikan pelatihan kombinasi footwork selama 12 kali pelatihan dengan tes yang sama seperti tes awal (pre-test). Selanjutnya dianalisis berdasarkan hasil pengukuran dari masingmasing kelompok.

Sebelum melakukan analisis data beberapa persyaratan yang harus dipenuhi adalah uji normalitas data dan uji homogenitas data.

a) Uji Normalitas Data

Uji normalitas data dimaksudkan untuk memperlihatkan bahwa sampel berasal dari populasi yang berdistribusi normal. Uji normalitas data dalam penelitian ini menggunakan uji Liliefors dengan bantuan SPSS 22.0 pada taraf signifikasi (a) 0,05. Kriteria pengambilan keputusan jika nilai signifikansi yang diperoleh lebih besar dari a (sig > 0,05), maka sampel berasal dari populasi yang berdistribusi normal, sedangkan jika nilai signifikansi yang diperoleh lebih kecil dari $\alpha($ sig < 0,05), maka sampel bukan berasal dari populasi yang berdistribusi normal (Candiasa, 2006:2).

b) Uji Homogenitas Data

Uji homogenitas data dimaksudkan untuk memperlihatkan bahwa dua atau lebih kelompok data sampel berasal dari populasipopulasi yang memiliki variasi yang sama. Uji homogenitas data dalam penelitian ini menggunakan uji Levene dengan bantuan program SPSS 22.0 taraf signifikansi (a) 0,05. Kriteria pengambilan keputusan jika nilai signifikansi Levene lebih besar dari pada a (sig Levene > 0,05), maka sampel homogen, sedangkan jika nilai signifikasi Levene lebih kecil dari pada a (sig Levene < 0,05) maka sampel tidak homogen (Candiasa, 2006:4)

\section{HASIL DAN PEMBAHASAN}

Penelitian ini dilakukan pada seluruh siswa peserta ekstrakurikuler bulutangkis SMP Muhammadiyah 2 Singaraja. Dalam penelitian ini kelompok eksperimen diberikan perlakuan berupa pelatihan kombinasi footwork. Data hasil pengukuran kelincahan dan $\mathrm{VO}_{2}$ Maks diperoleh dari pre-test dan post-test, kemudian nilai-nilai tersebut dianalisis dengan menggunakan SPSS 22.0 for windows. Pengukuran data pre-test diambil pada awal kegiatan penelitian sebelum subjek penelitian diberikan perlakuan, sedangkan data post-test diambil pada akhir kegiatan penelitian setelah subjek penelitian diberikan perlakuan selama 12 kali pelatihan.

\subsection{Deskripsi data hasil penelitian kelincahan pada kelompok perlakuan}

Deskripsi data pre-test kelincahan pada kelompok perlakuan yaitu, jumlah subjek penelitian sebanyak 15 orang, mean sebesar 21.8867, variance sebesar 2.153, standar deviation sebesar 2.16031, minimum sebesar 18.70, maximum sebesar 25.90 , range sebesar 7.20.

Deskripsi data post-test hasil penelitian kelincahan pada kelompok perlakuan yaitu, jumlah subjek penelitian sebanyak 15 orang, mean sebesar 18.8333, variance sebesar 1.452, standar deviation sebesar 1.20515, 
minimum sebesar 17.10 , maximum sebesar 21.40 , range sebesar 4.30 .

Dari data pre-test dan post-test diperoleh nilai beda (gain score) yang merupakan selisih dari hasil pengurangan data post-test dan pre-test. data gain score kelincahan pada kelompok perlakuan yaitu mean sebesar 3.0534 , variance sebesar 0.701, standar deviation sebesar 0.95516, minimum sebesar 1.6, maximum sebesar 4.5, range sebesar 2.9. Yang selanjutnya dianalisis dengan uji T-independent dengan bantuan program SPSS 22.0 untuk hasil uji hipotesis penelitian.

\subsection{Deskripsi data hasil penelitian kelincahan pada kelompok kontrol}

Deskripsi data pre-test hasil penelitian kelincahan pada kelompok kontrol yaitu, jumlah subjek penelitian sebanyak 15 orang, mean sebesar 21.5867, variance sebesar 2.153, standar deviation sebesar 1.46720 , minimum sebesar 19.20 , maximum sebesar 24.30 , range sebesar 5.10.

Deskripsi data post-test hasil penelitian kelincahan pada kelompok kontrol yaitu, jumlah subjek penelitian sebanyak 15 orang, mean sebesar 19.7333, variance sebesar 0.845, standar deviation sebesar 0.91937, minimum sebesar 18.50 , maximum sebesar 21.50 , range sebesar 3.00 .

Dari data pre-test dan post-test diperoleh nilai beda (gain score) yang merupakan selisih dari hasil pengurangan data post-test dan pre-test. data gain score kelincahan pada kelompok kontrol yaitu mean sebesar 1.8533, variance sebesar 1.308, standar deviation sebesar 0.54783, minimum sebesar 0.7 , maximum sebesar 2.8, range sebesar 2.1. Yang selanjutnya dianalisis dengan uji T-independent dengan bantuan program SPSS 22.0 untuk hasil uji hipotesis penelitian.

\subsection{Deskripsi data hasil penelitian $\mathrm{VO}_{2}$ Maks pada kelompok perlakuan}

Deskripsi data pre-test hasil penelitian $\mathrm{VO}_{2}$ Maks pada kelompok perlakuan yaitu, jumlah subjek penelitian sebanyak 15 orang, mean sebesar 33.1733, variance sebesar 41.811, standar deviation sebesar 6.46612 minimum sebesar 20.80, maximum sebesar 42.20 , range sebesar 21.40 .

Deskripsi data post-test hasil penelitian kelincahan pada kelompok perlakuan yaitu, jumlah subjek penelitian sebanyak 15 orang, mean sebesar 37.1333 , variance sebesar 32.264, standar deviation sebesar 5.68012, minimum sebesar 27.20, maximum sebesar 45.50, range sebesar 18.30 .

Dari data pre-test dan post-test diperoleh nilai beda (gain score) yang merupakan selisih dari hasil pengurangan data post-test dan pre-test. data gain score kelincahan pada kelompok perlakuan yaitu mean sebesar 3.96, variance sebesar -9.547, standar deviation sebesar 0.786, minimum sebesar 6.4, maximum sebesar 3.3, range sebesar -3.1. Yang selanjutnya dianalisis dengan uji Tindependent dengan bantuan program SPSS 22.0 untuk hasil uji hipotesis penelitian.

\subsection{Deskripsi data hasil penelitian $\mathrm{VO}_{2}$ Maks pada kelompok control}

Deskripsi data pre-test hasil penelitian $\mathrm{VO}_{2}$ Maks pada kelompok kontrol yaitu, jumlah subjek penelitian sebanyak 15 orang, mean sebesar 33.7267, variance sebesar 45.989, standar deviation sebesar 6.78154 , minimum sebesar 22.00, maximum sebesar 42.20 , range sebesar 20.20.

Deskripsi data post-test hasil penelitian kelincahan pada kelompok kontrol yaitu, jumlah subjek penelitian sebanyak 15 orang, mean sebesar 36.2933, variance sebesar 54.331, standar deviation sebesar 7.37093, minimum sebesar 24.00 , maximum sebesar 44.00 , range sebesar 20.00 .

Dari data pre-test dan post-test diperoleh nilai beda (gain score) yang merupakan selisih dari hasil pengurangan data post-test dan pre-test. data gain score kelincahan pada kelompok kontrol yaitu mean sebesar 2.5667, variance sebesar 8.342, standar deviation sebesar 0.58939 , minimum 
sebesar 2, maximum sebesar 1.8, range sebesar -0.2. Yang selanjutnya dianalisis dengan uji T-independent dengan bantuan program SPSS 22.0 untuk hasil uji hipotesis penelitian.

Tabel 4.5 Hasil Uji Normalitas data

\begin{tabular}{|c|c|c|c|c|c|}
\hline \multirow{2}{*}{ Sumber Data } & & \multicolumn{3}{|c|}{ Kolmogorov-Smirnov ${ }^{a}$} & \multirow{2}{*}{ Keterangan } \\
\hline & & Statisti & & Sig. & \\
\hline \multirow[t]{2}{*}{ Kelincahan } & Perlakuan & 0.104 & 15 & 0.200 & Data berdistribusi normal \\
\hline & Kontrol & 0.113 & 15 & 0.200 & Data berdistribusi normal \\
\hline \multirow[t]{2}{*}{$\mathrm{VO}_{2}$ Maks } & Perlakuan & 0.148 & 15 & 0.200 & Data berdistribusi normal \\
\hline & Kontrol & 0.122 & 15 & 0.200 & Data berdistribusi normal \\
\hline
\end{tabular}

Pengujian terhadap normalitas data kelincahan kelompok perlakuan 0.104 dengan penelitian dilakukan pada data gain score dari signifikansi 0.200 , sedangkan variabel data kelincahan dan $\mathrm{VO}_{2}$ Maks dengan kelincahan kelompok kontrol 0.113 dengan instrumen uji Kolmogorov-Smirnov dengan signifikansi 0.200 . Hasil untuk variabel $\mathrm{VO}_{2}$ bantuan program SPSS 22.0 pada taraf Maks kelompok perlakuan 0.148 dengan signifikansi (a) 0,05. Data akan berdistribusi signifikansi 0.200 , sedangkan variabel $\mathrm{VO}_{2}$ normal jika nilai signifikansi hitung data yang Maks kelompok kontrol 0.122 dengan diujikan lebih besar dari pada $\alpha$ (sig > 0,05). signifikansi 0.200. Pada taraf signifikansi $\alpha=$ Rangkuman hasil uji normalitas data untuk 0.05 signifikansi variabel kelincahan dan $\mathrm{VO}_{2}$ variabel tersebut dapat dilihat pada tabel 4.5 . Maks lebih besar dari pada a (sig > 0.05) sehingga data yang diuji merupakan data yang berdistribusi normal. Maka akan dilakukan uji hipotesis dengan menggunakan statistik Instrumen Uji Kolmogorof- Smirnov program SPSS 22.0 diperoleh hasil untuk variabel parametrik.

Tabel 1.6 Data Hasil Uji Homogenitas data

\begin{tabular}{cccccc}
\hline Sumber Data & Levene & df1 & df2 & Sig. & Keterangan \\
Kelincahan & Statistic & & & & \\
$\mathrm{VO}_{2}$ Maks & 0.142 & 1 & 28 & 0.709 & Homogen \\
\hline
\end{tabular}

Pengujian homogenitas data dilakukan terhadap data post-test kelincahan dan $\mathrm{VO}_{2}$ Maks. Dari hasil analisis uji Levene dengan bantuan SPSS 22.0 pada taraf signifikansi $(\alpha)$ 0.05 . Dari hasil uji didapatkan nilai signifikansi hitung untuk kedua data tersebut lebih besar dari pada a (sig >0.05), dengan demikian data yang diuji berasal dari data dengan variansi yang homogen.

Dari hasil uji homogenitas menggunakan instrumen uji levene dengan bantuan program SPSS 22.0 pada pelatihan kombinasi footwork diperoleh nilai uji untuk variabel kelincahan 0.142 dengan signifikansi 0.709 , sedangkan nilai uji untuk variabel $\mathrm{VO}_{2}$ Maks 1.753 dengan signifikansi 0.196. Pada taraf signifikansi $\alpha=0,05$ signifikansi variabel $\mathrm{VO}_{2}$ Maks dan kelincahan lebih besar dari pada $\alpha$ (sig $>0,05)$ sehingga data yang diuji berasal dari data yang homogen. Maka akan dilakukan uji hipotesis dengan menggunakan statistik parametrik 
Tabel 4.7 Hasil Uji-t Independent Kelincahan

Independent Samples Test

Sumber data t-test for Equality of Means

$\mathrm{T}$

2.238
Df

28
Sig. (2-tailed)

0.033
Hipotesis pelatihan kombinasi footwork berpengaruh terhadap peningkatan kelincahan dengan uji-t independent dengan bantuan program SPSS 22.0 pada taraf signifikansi $(\alpha)$ 0,05 . Hipotesis penelitian diterima apabila nilai uji-t memiliki signifikansi lebih kecil dari a (Sig $<0,05)$. Sedangkan apabila nilai signifikansi hitung lebih besar dari $\alpha$ (Sig $>0,05)$, hipotesis penelitian ditolak.
Dari hasil uji-t independent didapat nilai variabel kelincahan sebesar 2.238 dengan signifikansi 0.033 . Pada taraf signifikansi $\alpha=$ 0,05 signifikansi variabel kelincahan 0.033 lebih kecil dari nilai a (Sig < 0,05), sehingga hipotesis penelitian pelatihan kombinasi footwork variabel kelincahan diterima

Tabel 4.8 Hasil Uji-t Independent $\mathrm{VO}_{2}$ Maks

\section{Independent Samples Test}

Sumber data

$\mathrm{VO}_{2}$ Maks

Hipotesis pelatihan kombinasi footwork berpengaruh terhadap $\mathrm{VO}_{2}$ Maks diuji dengan uji-t independent dengan bantuan program SPSS 22.0 pada taraf signifikansi (a) 0,05. Hipotesis penelitian diterima apabila nilai uji-t memiliki signifikansi lebih kecil dari a (Sig < 0,05). Sedangkan apabila nilai signifikansi hitung lebih besar dari $\alpha$ (Sig >0,05), hipotesis penelitian ditolak.

Dari hasil uji-t independent didapat nilai variabel $\mathrm{VO}_{2}$ Maks 2.397 dengan signifikansi 0.023. Pada taraf signifikansi $\alpha=0,05$ signifikansi variabel $\mathrm{VO}_{2}$ Maks $=0.023$ lebih kecil dari nilai a (Sig < 0,05), sehingga sehingga hipotesis penelitian pelatihan kombinasi footwork variabel $\mathrm{VO}_{2}$ Maks diterima.

\footnotetext{
Secara teoritis, hasil penelitian metode latihan kombinasi footwork berpengaruh terhadap peningkatan kelincahan dan $\mathrm{VO}_{2}$ Maks. Maka untuk meningkatkan kondisi fisik pada siswa SMP, harus dapat meningkatkan kemampuan komponen kondisi fisik secara menyeluruh karena berdasarkan fakta bahwa selalu ada saling keterkaitan antara semua organ dan sistem organ manusia dan antara
}

t-test for Equality of Means

Sig. (2-tailed)

Df

28

proses fisiologis dan psikologis. Dengan melakukan berbagai aktivitas fisik, maka makin banyak unsur biomotorik yang akan berkembang sehingga akan menunjang pencapaian kondisi fisik yang baik, dan kondisi fisik yang baik akan memberikan manfaat yang besar terhadap pencapaian prestasi yang optimal. Berdasarkan hal tersebut pelatihan kombinasi footwork dilihat paling efektif untuk meningkatkan kelincahan dan $\mathrm{VO}_{2}$ Maks pada siswa ekstrakurikuler bulutangkis SMP Muhammadiyah 2 Singaraja.

Dari hasil analisis data untuk variabel terikat penelitian menunjukan adanya peningkatan nilai rata-rata (mean) untuk masing-masing variabel. Dari deskripsi data variabel kelincahan pada tabel 4.1 terlihat kelompok perlakuan. Nilai pre-test kelompok perlakuan memiliki mean 21.8867 dan mean post-test 18.8333, dengan demikian nilai ratarata kelompok perlakuan meningkat 3.0534. Pada tabel 4.2 Nilai pre-test kelompok kontrol memiliki mean 21.5867 dan mean post-test 19.7333, dengan demikian nilai rata-rata kelompok perlakuan meningkat 1.8534 . 
Untuk variabel $\mathrm{VO}_{2}$ Maks seperti terlihat pada tabel 4.3 mengalami peningkatan ratarata baik pada kelompok perlakuan maupun kelompok kontrol. Kelompok perlakuan mengalami peningkatan mean sebesar 33.1733 dan mean post-test 37.1333 , dengan demikian nilai rata-rata kelompok perlakuan meningkat 3.96. Sedangkan kelompok kontrol pada tabel 4.4 mengalami peningkatan mean sebesar 33.7267 dan mean post-test 36.2933, dengan demikian nilai rata-rata kelompok perlakuan meningkat 2.5666 .

Dari deskripsi di atas, terlihat adanya peningkatan nilai variabel kelincahan pada kelompok perlakuan maupun kontrol dan peningkatan nilai variabel $\mathrm{VO}_{2}$ Maks pada kelompok perlakuan maupun kelompok kontrol. Dengan peningkatan rata-rata kelompok perlakuan yang lebih tinggi dari pada kelompok kontrol untuk variabel kelincahan dan peningkatan rata-rata kelompok perlakuan yang lebih tinggi dari pada kelompok kontrol untuk variabel $\mathrm{VO}_{2}$ Maks. Hal ini menunjukkan adanya pengaruh dari pelatihan yang diberikan terhadap peningkatan kelincahan dan $\mathrm{VO}_{2}$ Maks pada subjek penelitian. Peningkatan pada kelompok perlakuan diakibatkan oleh pemberian pelatihan kombinasi footwork selama 4 minggu atau 12 kali pelatihan. Sedangkan peningkatan pada kelompok kontrol lebih diakibatkan oleh adanya peningkatan aktivitas olahraga yang dilakukan oleh seluruh subjek penelitian selama kegiatan berlangsung

\section{SIMPULAN DAN SARAN}

Berdasarkan hasil penelitian analisis data, dan pembahasan dapat diperoleh simpulan sebagai berikut : (1) Metode Pelatihan kombinasi footwork berpengaruh signifikan terhadap peningkatan kelincahan pada siswa peserta ekstrakurikuler bulutangkis SMP Muhammadiyah 2 Singaraja. (2) Pelatihan kombinasi footwork berpengaruh signifikan terhadap peningkatan $\mathrm{VO}_{2}$ Maks pada siswa peserta ekstrakurikuler bulutangkis SMP Muhammadiyah 2 Singaraja

Hal-hal yang dapat disarankan adalah sebagai berikut: (1) Bagi pelatih dan pembina olahraga merupakan pengetahuan untuk menyusun suatu program pelatihan yang lebih berkualitas sehingga dapat melatih siswa untuk berkembang secara optimal sesuai dengan potensi yang dimiliki. Sehingga dapat menambah alternatif bentuk pelatihan untuk kelincahan dan $\mathrm{VO}_{2}$ Maks. (2) Bagi siswa merupakan pengalaman yang dapat dimanfaatkan untuk melatih kelincahan dan $\mathrm{VO}_{2}$ Maks. (3) Bagi peneliti dapat dimanfaatkan sebagai kajian ilmiah dan pertimbangan dalam penelitian selanjutnya. (4) Bagi masyarakat merupakan pengetahuan baru yang dapat diterapkan untuk latihan bagi setiap warga yang memiliki potensi dalam olahraga bulutangkis. (5) Bagi atlet pelatihan ini nantinya bisa di terapkan dalam pelatihan cabang olahraga yang menggunakan kelincahan dan $\mathrm{VO}_{2}$ Maks dan dapat digunakan sebagai alternatif teknik dalam meningkatkan kemampuan kelincahan dan $\mathrm{VO}_{2}$ Maks.

\section{DAFTAR PUSTAKA}

Candiasa, Made. 2006. "Program SPSS" Bahan Pelatihan Komputer dan Multimedia Pada Jurusan IImu Keolahragaan. Singaraja: Undiksha.

Depdiknas. (2000). Pedoman dan Modul Pelatihan Kesehatan Olahraga Bagi Pelatih Olahragawan dan Pelajar. Jakarta: Depdiknas.

Herman Subarjah. Pengaruh Model Latihan Terhadap Hasil Belajar Ketrampilan Bermain Bulutangkis. Jurnal IPTEK Olahraga. Kementerian Pemuda dan Olahraga RI. VOL 12, No 2, Mei-Agustus 2010.ISSN:1411-0016

Hermawan Aksan. 2013. Mahir Bulutangkis. Bandung: Nuansa Cendekia.

Ismaryati. 2009. Tes dan pengukuran olahraga. Surakarta LPP UNS dan UNS

Kanca, I Nyoman. 2004. Pengaruh Pelatihan Fisik Aerobik Dan Anaerobik Terhadap Absorpsi Karbohidrat Dan Protein Di Usus Halus Rattus Norvegicus Strain Wistar. Surabaya: Disertasi Doktor IImu Kedokteran Universitas Airlangga. 
Kanca. I Nyoman. 2010. Metode Penelitian Pengajaran Pendidikan Jasmani dan Olahraga. Singaraja: Pendidikan Jasmani Kesehatan dan Rekreasi Fakultas Olahraga dan Kesehatan Universitas Pendidikan Ganesha.

M. Kidnesia. 2011. Cara Kerja Otot Kaki. Tersedia pada sumber: http://m.kidnesia.com/kidnesia/DariKamu/ Tanya-Nesi/Pelajaran- Sekolah/CaraKerja-Otot-Kaki (diakses tanggal 12 Desember 2015)

Nurhasan. 2000. Tes dan Pengukuran Pendidikan Olahraga. Jakarta: Fakultas Pendidikan Olahraga dan Kesehatan Universitas Pendidikan Indonesia.

Nala, Ngurah. 2015. Prinsip Pelatihan Fisik Olahraga. Denpasar: Program Pasca Sarjana UNUD.

Poole. James. 2011. Belajar Bulutangkis. Bandung: Pionir Jaya

Rusli lutan, Hartoto, Tomoliyus. (2002). Pendidikan Kebugaran Jasmani: Orientasi Pembinaan Sepanjang Hayat. Jakarta: Penerbit Departemen Pendidikan Nasional.

Robergs, R., A, B, C and D. 2000. Incidence of the Oxygen Plateauat $\mathrm{VO}_{2}$ max during Exercise Testing to Volitional Fatigue. Journal of The American Society of Exercise Physiologists.

Sharkley, 2011. Kebugaran dan Kesehatan. Rajawali Sport, Devisi Buku Olahraga \& Kesehatan. PT. Raja Grafindo Persada. $75-85$.

Sukadiyanto. 2005. Pengantar Teori dan Pelatihan Metodelogi Melatih Fisik. Fakultas IImu Keolahragaan Universitas Negeri Yogyakarta.

Sukadiyanto. 2011. Pengantar Teori dan Metodologi Melatih Fisik. Bandung: lubuk agung.

Setijono, Hari, dkk. 2001. Instruktur Fitness. Surabaya: Unesa University Press.
Swadesi, I Ketut Iwan. 2007. "Pengaruh Pelatihan Sirkuit Periode Istirahat 30 Detik dan 60 Detik terhadap VO2 Maks, Kelincahan dan Volume Oksigen Maksimal pada Pemain Bola Basket". Jurnal Penelitian dan Pengembangan Sains \& Humaniora, Volume 1, Edisi 1 (hlm.37-52). Tersedia pada http://ebookbrowse.com/i-ketutiwanswadesi-pdf-d100259475

Widiastuti. 2015, Tes dan Pengukuran Olahraga. -Ed. 1-2. -Jakarta : Rajawali Pers 2017. 